УДК 341.123

Степко Олександр Михайлович

кандидат політичних наук, дочент,

Київський начіональний університет культури і мистецттв,

Київ, Украӥна,

stepko2004@ukr.net

\title{
ІНФОРМАЦІЙНА СКЛАДОВА ОПЕРАЦІЙ ООН 3 ПІДТРИМАННЯ МИРУ
}

Актуальність теми випливає із необхідності дослідження інформаційної складової операцій ООН з підтримання миру, що є важливим інструментом для досягнення ії цілей у сфері забезпечення миру та безпеки. Мета дослідження проаналізувати інформаційне забезпечення операцій $\mathrm{OOH} з$ підтримання миру. Методологічною основою дослідження $€$ загальнонаукові принципи дослідження. При дослідженні інформаційних механізмів системи $\mathrm{OOH}$ застосовувалися системний і аналітичний методи з притаманними їм аналізом та синтезом. Історичний підхід дозволив простежити еволюцію діяльності ООН в області інформаційного забезпечення миротворчості. Комплексне використання різноманітних методів дозволило створити сучасну картину інформаційного забезпечення операцій $\mathrm{OOH} 3$ підтримання миру. Протягом останнього десятиліття $\mathrm{OOH}$ неодноразово виявлялася не в змозі ефективно вирішити конфлікт, і сьогодні iї потенціал у цій області не підвищився. Негативні результати у багатьох випадках були наслідком того, що засоби, які надавалися в розпорядження Організації, не відповідали вимогам, що пред’являлися до неї.

Ключові слова: Інформаційна діяльність $\mathrm{OOH}$, інформаційне забезпечення, миротворчі операції ООН, Департамент операцій з підтримання миру.

Stepko Oleksandr, Candidate of Political Sciences, Associate Professor, Kyiv National University of Culture and Arts, Kyiv, Ukraine

Informational component of the United Nations peacekeeping operations

The relevance of the topic arises from the need to research the information component of the UN peacekeeping operations, being an important tool for achieving its goals in the area of peace and security. The objective of the study is to analyze the information support for the UN peacekeeping operations. The methodological basis of the research is general scientific research principles. Researching the information mechanisms of the UN system, systematic and analytical methods were used with their inherent analysis and synthesis. The historical approach made it possible to trace the evolution of the UN activities in the field of the information support for peacekeeping. The comprehensive use of various methods allowed the creation of a modern picture of 
the information support for the UN peacekeeping operations. Over the past decade, the UN has repeatedly failed to effectively resolve the conflict, and today its potential has not been improved in this area yet. Negative results in many cases were the consequence of the fact that the facilities available to the Organization did not meet the requirements.

Key words: UN information activities, informational providing, UN peacekeeping operations, Department of Peacekeeping Operations.

Степко Александр Михайлович, кандидат политических наук, дочент, Киевский национальный университет культуры и искусств, Киев, Украина

Информационная составляющая операций ООН по поддержанию мира

Актуальность темы вытекает из необходимости исследования информационной составляющей операций $\mathrm{OOH}$ по поддержанию мира, которая является важным инструментом для достижения ее целей в сфере обеспечения мира и безопасности. Цель исследования - проанализировать информационное обеспечение операций $\mathrm{OOH}$ по поддержанию мира. Методологической основой исследования являются общенаучные принципы исследования. При исследовании информационных механизмов системы ООН применялись системный и аналитический методы с присущими им анализом и синтезом. Исторический подход позволил проследить эволюцию деятельности ООН в области информационного обеспечения миротворчества. Комплексное использование различных методов позволило создать современную картину информационного обеспечения операций $\mathrm{OOH}$ по поддержанию мира. В течение последнего десятилетия ООН неоднократно оказывалась не в состоянии эффективно решить конфликт, и сегодня ее потенциал в этой области не повысился. Отрицательные результаты во многих случаях были следствием того, что средства, которые предоставлялись в распоряжение Организации, не соответствовали требованиям, предъявляемым к ней.

Ключевые слова: Информационная деятельность $\mathrm{OOH}$, информационное обеспечение, миротворческие операции ООН, Департамент операций по поддержанию мира.

Вступ. За останні десятиліття у світі відбулися глибокі зміни, що проявилися, зокрема, в зростанні ролі інформації - іï вплив можна порівняти із впливом промислової революції, Інтернет став найбільш швидко зростаючим засобом комунікації за всю історію цивілізації. Інформація $є$ рушійною силою, що сприяє порозумінню між народами і розширенню участі людей у прийнятті рішень, що впливають на їхнє життя.

Широка підтримка світової спільноти є запорукою успішної діяльності ООН. У цьому зв'язку комунікаційна робота відіграє для Організації дуже 
важливу роль. Без інформаційного забезпечення неможливо досягти основних цілей $\mathrm{OOH}$ - воно стає все більш важливим аспектом покращення ефективності миротворчих операцій. Миротворча діяльність не буде успішною, якщо люди не розумітимуть мету та сутність дій миротворців.

Забезпечення міжнародного миру і безпеки - це одна з головних причин створення ООН. Підтримання миру є частиною набагато ширших зусиль, яких докладає ООН для справи миру. ООН застосовує превентивну дипломатію для ліквідації конфлікту ще до того, як він вибухне, а також постконфліктне миробудівництво для створення умов стійкого миру та усунення причин нового конфлікту. На всіх цих етапах ефективне використання інформації є життєво необхідним.

Таким чином, актуальність теми випливає із необхідності дослідження інформаційної складової операцій $\mathrm{OOH} з$ підтримання миру, що є важливим інструментом для досягнення іï цілей у сфері забезпечення миру та безпеки.

Мета дослідження: проаналізувати інформаційне забезпечення операцій $\mathrm{OOH}$ з підтримання миру.

Виклад основного матеріалу. Провідні політичні лідери та експерти завжди приділяли інформаційним проблемам дуже серйозну увагу. Серед закордонних дослідників, що обгрунтовували роль інформації у світі, необхідно виділити роботи А. Гора, 3. Бжезинського, М. Маклухана, А. Тоффлера та ін. Велику увагу інформаційному розвитку продовжують приділяти Генеральні Секретарі $\mathrm{OOH}$, серед яких особливий внесок в інформаційне забезпечення миротворчості зробили П. де Куельяр, Б. Галі, К. Аннан та А. Гутерреш.

Серед українських вчених, що досліджують роль інформації, інформаційні відносини та роль міжнародних організацій в них, хотілося б виділити Г. Г. Почепцова, О. В. Зернецьку, О. В. Литвиненка та Є. А. Макаренко. Серед робіт українських дослідників, які торкаються миротворчої роботи $\mathrm{OOH}$, варто відзначити праці В. С. Бруза, Л. І. Скороход, Ю. С. Скорохода та ін.

$\mathrm{У}$ сфері забезпечення миру і безпеки ООН займається головним чином внутрішньодержавними конфліктами, що нерідко мають серйозні міжнародні наслідки i часто позв'язані 3 гуманітарними надзвичайними ситуаціями. Механізм ООН 3 підтримки миру $є$ швидкою допомогою і стримуючою військовою силою для міжнародного співтовариства. Негативні результати у багатьох випадках були наслідком того, що засоби, які надавалися в розпорядження Організації, не відповідали вимогам, що пред'являлися до неї.

У наш час сформувалася концепція операцій з підтримки миру (ОПМ), елементи якої можна сформулювати так: ОПМ здійснюються насамперед 3 метою попередження конфліктів і мирного вирішення спорів; підготовка i проведення таких операцій тісно координуються з регіональними організаціями $\mathrm{i}$ пов'язуються з політичним врегулюванням і гарантіями з боку Ради Безпеки чи іï постійних членів; розширюється сфера застосування сил з підтримки миру; 
операції поєднуються 3 рішенням економічних, соціальних і гуманітарних проблем відповідних країн і регіонів; створюється єдина система підготовки національних контингентів; встановлюється правова i фінансова основа діяльності сил з підтримки миру.

Основи теорії і практики діяльності ООН у сфері підтримання миру та іiі інформаційного забезпечення викладені у таких доповідях Генсеків ООН як «Порядок денний для миру: превентивна дипломатія, миротворчість та підтримка миру» Б. Галі [3] та «Ми, народи: роль ООН у ХXI столітті» К. Аннана [4].

Серед головних шляхів забезпечення миру та безпеки відзначають превентивну дипломатію, миротворчість, підтримку миру та постконфліктне миробудівництво. Найбільш бажане й ефективне застосування дипломатії - це до того, як напруженість переросте в конфлікт, чи якщо він почався - вживання негайних заходів для стримування й усунення його причин. ООН має потребу в ранньому попередженні, зборі інформації й аналізі фактів. Для цього може відбуватися обмін військовими місіями; можна створити регіональні центри зі зменшення небезпеки; повинен бути вільний потік інформації і спостереження за виконанням угод.

Превентивні кроки мають грунтуватися на своєчасних і точних фактах. Для ООН необхідна інформація повинна охоплювати економічні і соціальні тенденції, а також політичні події. Необхідно частіше застосовувати процедуру встановлення фактів. Усі держави повинні бути готові надати інформацію, необхідну для ефективної діяльності ООН. Місії для збору фактів санкціонує Рада Безпеки чи Генеральна Асамблея ООН. Крім того, ці місії можуть допомагати улагоджувати суперечки однією своєю присутністю. В області раннього попередження існує необхідність зміцнення механізму так, щоб була можливість синтезувати інформацію з політичними показниками, для визначення погрози миру і дій ООН.

Для реального успіху ОПМ повинні містити в собі зусилля зі встановлення і підтримки структур, необхідних для зміцнення миру і підвищення впевненості і благополуччя. Така діяльність може містити в собі, зокрема: консультації персоналу для забезпечення безпеки, нагляд за виборами, захист прав людини, реформу і зміцнення урядових закладів. Після війни такі заходи включають здійснення проектів, що зв’язують країни, підвищення довіри, обмін у сфері освіти, культурний обмін та ін.

У XXI ст. формується нова концепція безпеки, основою якої є захист усього населення і конкретних людей від насильства, породженого усередині держави. Ці нові задачі змушують ООН коректувати традиційні концепції. У зв'язку з цим, більш широке використання інформаційних технологій може сприяти зменшенню страждань для людей у період надзвичайних ситуацій. Тоді як у центрі традиційних ОПМ були головним чином зусилля зі спостереження за припиненням вогню, сьогоднішні комплексні миротворчі операції носять зовсім 
інший характер. Їх ціль полягає в тому, щоб допомогти конфліктуючим сторонам забезпечувати свої інтереси політичними засобами. 3 цією метою ООН сприяє створенню і зміцненню політичних установ, а також розширенню їхньої бази. Організація працює разом із урядами і місцевим населенням, для того щоб доставляти гуманітарну допомогу, налагоджувати комунікації та ін.

Протягом останнього десятиліття ООН неодноразово виявлялася не в змозі ефективно вирішити конфлікт, і сьогодні іï потенціал у цій області не підвищився. Тому були проведені дослідження ООН з метою встановлення причин цих невдач. Ці дослідження показали, як недостатня політична воля, неадекватні мандати РБ і нестача ресурсів, поряд із недоліками самої $\mathrm{OOH}$, сприяли провалу. Було зроблено висновки, до яких, зокрема, відносяться важливість спільних дій держав-членів і Секретаріату; необхідність поліпшення обміну інформацією як між державами-членами і Секретаріатом, так і в рамках самого Секретаріату; і потреба в більш ефективному і своєчасному аналізі інформації, що надходить $з$ місць.

Деякі ОПМ були започатковані міжнародним співтовариством багато в чому для того, щоб створити видимість уживання заходів. Експерти закликали відмовитися від півзаходів і перейти до чіткого плану дій, що має широку підтримку. У тих випадках, коли передумов для успішних дій не існує, краще взагалі не проводити операції; коли ж дії починаються, операції повинні бути набагато краще оснащені і мати більш вагому підтримку.

Стратегічний підхід ООН до запобігання конфліктів вимагає більш тісної взаємодії між головними оперативними департаментами Секретаріату, що займаються питаннями миру i безпеки. 3 цією метою вони будуть мати потребу в більш удосконалених інструментах збору й аналізу відповідної інформації і підтримки Виконавчого комітету з питань миру і безпеки (ВКМБ), який сприяє більш широкому обміну інформацією і співробітництву між департаментами.

Професійна система для накопичення знань у відношенні конфліктних ситуацій, ефективного поширення цих знань серед широкого кола користувачів, підготовки аналітичних оцінок політики i формулювання довгострокових стратегій створена у вигляді секретаріату ВКМБ з інформаційно-стратегічного аналізу (СICA). Основні задачі цього секретаріату полягають у наступному: забезпечувати основне секретаріатське обслуговування Комітету, а також міждепартаментську роботу у зв'язку з запобіганням конфліктів; служити координуючим центром для розробки стратегій комплексного характеру, що вимагають багатодисциплінарного підходу, при якому політичні, соціальноекономічні та гуманітарні фактори зливалися б у єдине ціле; служити внутрішнім центром акумуляції знань для працівників шляхом вивчення й аналізу питань в області підтримки миру і безпеки; служити координаційним центром для застосування сучасних інформаційних систем і технологій у роботі всіх 
елементів системи ООН, що беруть участь у підтримці миру і безпеки; робити поширення і нагромадження інформації більш оперативним і ефективним.

Одна 3 найголовніших функцій СІСА полягає в тому, щоб надавати Генсеку і членам ВКМБ узагальнені оцінки зусиль ООН та ін. установ з усунення причин конфліктів і оцінювати потенційну користь від подальшого залучення ООН. Він надає базову довідкову інформацію для первісної роботи комплексних цільових груп із планування місій та забезпечує аналіз і керування інформаційним потоком між місією $\mathrm{i}$ цільовою групою 3 моменту започаткування місії.

CICA створений також для того, щоб вести і використовувати комплексні бази даних (БД), що доповняють, а часом і замінюють телеграми, щоденні оперативні дані, добірки інформаційних матеріалів і неофіційні контакти 3 колегами, які використовуються начальниками підрозділів для того, щоб бути в курсі подій. Такі БД, що можуть використовуватися як Центральними установами, так і польовими операціями, можуть зробити справжню революцію в плані того, як ООН накопичує знання й аналізує ключові питання миру $\mathrm{i}$ безпеки. Створення СІCА $€$ також корисним для РБ і країн, що надають військові контингенти, оскільки допомагає поліпшити зміст аналітичного компоненту операцій у рамках нових місій. Отже, СІСА повинен стати механізмом більш раціонального використання інформації, яка вже $\epsilon$ в системі ООН.

Цікавою проблемою є потенціал ООН в області суспільної інформації, який може бути використаний в миротворчих операціях. Як вже відзначалося, практично для всіх операцій $\mathrm{OOH}$ потенціал в області суспільної інформації $\mathrm{i}$ комунікації в районах місії є оперативною необхідністю. Ефективне поширення інформації допомагає боротися зі слухами $\mathrm{i}$ дезінформацією і дозволяє заручатися підтримкою місцевого населення. Воно може стати важелем тиску на лідерів протиборчих угруповань, підвищити безпеку персоналу ООН і виступати як посилювач впливу. Тому надзвичайно важливо, щоб кожна ОПМ розробила стратегії кампаній в області інформації, особливо у відношенні ключових аспектів мандата місії, і щоб найперша група, що направляється для сприяння розгортанню нової місії, вже мала у своєму розпорядженні такі стратегії і включала у свій склад персонал, необхідний для їхнього здійснення.

Польові місії мають потребу у співробітниках, що представляли б місію в рамках повсякденних контактів із громадськістю. Для ефективної роботи вони повинні мати досвід роботи, а також знати, як діють місії і Центральні установи ООН. Крім того, необхідно, щоб польові операції ООН могли ефективно поширювати інформацію серед своїх власних співробітників, інформувати їх про політику місії і подій, що трапляються і зміцнювати зв'язки між компонентами, а також між вищими і нижчими інстанціями. Нові інформаційні технології являють собою ефективний інструмент забезпечення такої комунікації і повинні включатися в комплекти спорядження першої необхідності. 
За даними ООН, обсяг ресурсів, що виділяються на діяльність в області суспільної інформації не часто перевищує $1 \%$ оперативного бюджету місії [5, с. 2]. 3 огляду на вищесказане, можна зробити висновок про необхідність збільшення обсягу таких ресурсів, необхідних для поширення інформації про операцію, і на встановлення ефективних внутрішніх комунікаційних зв'язків для того, щоб привести ресурси у відповідність з мандатом і потребами місій. Щодо розвитку діяльності в області суспільної інформації, то досвід показує, що такі компоненти в ОПМ найчастіше недостатньо добре плануються чи їм не надається ефективна підтримка.

Важливою проблемою $є$ планування місій. До поч. 1990-х рр. планування ОПМ починалося після проведення в РБ голосування по відповідній резолюції. Воно зводилося до таких питань, як доставити військові частини в район передбачуваних дій і як організувати їхню підтримку, при відсутності комплексного підходу.

У результаті зростання попиту на проведення нових місій 3 підтримки миру виникла необхідність у створенні потенціалу оперативного планування. Поява нового покоління комплексних ОПМ, для яких властиві політичні, гуманітарні і військові аспекти, потребує більш серйозної координації i взаємодії, ніж колись, і зумовлює необхідність узгодження зусиль різних департаментів i установ. У Департаменті Операцій 3 Підтримки Миру виділяються спеціальні ресурси на удосконалювання процесу планування та функцій координації. Центральне місце в цьому процесі приділяється Службі планування місій, яка виступає як консультаційно-координаційний механізм для департаментів і зовнішніх організацій, що беруть участь у проведенні відповідної місії з підтримки миру [2]. ÏÏ ціль полягає в передбаченні виникнення кризової ситуації і плануванні вже на ранній стадії, ще до того, як Рада Безпеки дасть санкцію на проведення операції.

Служба розділена на ряд функціональних підрозділів, кожний з яких має свої інформаційні обов'язки. Група загального планування сприяє процесу планування за допомогою внесення рекомендацій 3 його поліпшення. Таке сприяння може здійснюватися через вироблення відповідної доктрини чи складання письмового посібника, крім цього вона відновляе стандартні оперативні процедури. Група організації місій відповідає за розробку загальних планів у відношенні здійснення нових польових місій і зміни діючих мандатів. На їх основі виробляються концепції оперативного забезпечення. Особи, що займаються плануванням місій, готують консультації з військових питань, використовуючи при цьому базу даних, в основі якої лежить зібрана інформація і досвід попередніх місій.

На відміну від компонентів місій, зв'язаних з військовими аспектами, цивільною поліцією та ін. аспектами, у Центральних установах немає жодного підрозділу, що конкретно відповідав би за задоволення оперативних потреб 
компонентів ОПМ, пов'язаних з інформацією. У найбільш сконцентрованому вигляді відповідальність за діяльність в області суспільної інформації в контексті місій лежить на Канцелярії Прес-секретаря Генерального секретаря і відповідних прес-секретарях i співробітниках із суспільної інформації самих місій. У Центральних установах за підготовку публікацій, розміщення і відновлення на веб-сайті матеріалів про операції на користь миру i рішення ін. питань відповідають співробітники у Секції з питань миру і безпеки Департаменту Публічної Інформації (ДПІ) [1]. Ця Секція готує й оновлює інформацію про миротворчу діяльність, але ії можливості в плані розробки стратегії стандартних оперативних процедур в області інформації на місцях дуже обмежені. За розміщення на веб-сайті всіх матеріалів, що стосуються питань миру і безпеки, а також всієї інформації, що направляється місіями для веб-сайту, відповідає недостатня кількість співробітників. Тому нинішній процес підготовки новин $\mathrm{i}$ розміщення матеріалів на веб-сайті $\mathrm{OOH} є$ доволі повільним. Це також обмежує обсяг інформації, яку можна привести по кожній місії. ДПІ і співробітники на місцях виявили зацікавленість у рішенні цієї проблеми шляхом розробки моделі «спільного управління веб-сайтом», що могло б стати оптимальним варіантом.

Одними з головних цілей миротворчих операцій $\mathrm{OOH}$ в інформаційному аспекті є: сприяти комунікації й обміну даними; надавати в розпорядження співробітників інструментарій, необхідний їм у їхній роботі; і в кінцевому рахунку створювати можливості для того, щоб ООН могла більш ефективно запобігати конфліктам і допомагати суспільствам виходити зі стану війни. Одним із ключів до досягнення багатьох з цих цілей $є$ сучасні інформаційні технології.

Питання стратегії і політики в області інформаційних технологій виходить за рамки миротворчих операцій і торкається всієї системи ООН. Однак більш значні питання не повинні перешкоджати застосуванню загальних підходів до використання інформаційних технологій у рамках ОПМ. Служба комунікації може забезпечити зв'язок через супутник і локальні мережі, завдяки чому місії можуть створювати ефективні інформаційні мережі і бази даних, але необхідно розробити досконалі стратегії, для того щоб допомогти користувачам в освоєнні основ технологій.

Коли ООН започатковує місію на місці, важливо, щоб ії елементи могли легко обмінюватися між собою даними. У рамках всіх комплексних ОПМ задіяно багато різних діючих осіб: департаменти Секретаріату, а також установи, фонди i програми системи $\mathrm{OOH}$; співробітники, що вперше з'явилися в системі $\mathrm{OOH}$; регіональні організації; двосторонні установи 3 надання допомоги; десятки неурядових організацій (НУО), що займаються гуманітарними питаннями i питаннями розвитку. Усі вони мають потребу в механізмі, що полегшував би ефективний обмін інформацією. 
Погано сплановані і погано інтегровані інформаційні технології можуть створювати перешкоди для налагодження такого співробітництва. Наслідки того, що на рівні прикладного програмного забезпечення немає погоджених стандартів, можуть бути критичними, починаючи від перекручування суті політики і закінчуючи нездатністю відчути серйозні зміни в оперативній обстановці.

Інформаційні технології можна було б використовувати більш раціонально, для того щоб допомогти широкому колу осіб, що діють у районі операцій місії $\mathrm{OOH}$, в одержанні даних і обміні ними на систематичній $\mathrm{i}$ взаємовигідній основі. Наприклад, установи $\mathrm{OOH}$, що займаються питаннями розвитку і гуманітарної допомоги, діють у більшості місць, де розгорнуті операції $\mathrm{OOH}$ на користь миру. Ці групи на рівні країн ООН і НУО, що займаються додатковою діяльністю на низовому рівні, з'являються в регіоні задовго до розгортання комплексної операції на користь миру, i вони залишаються там після іiї згортання. Разом узяті вони мають багатий досвід i знання, які вони придбали за рахунок роботи в місцевих умовах і які могли б виявитися корисними при плануванні і здійсненні ОПМ. Центр аналізу й обробки електронних даних міг би допомогти при плануванні і здійсненні місії, а також сприяти у справі запобігання й оцінки конфліктів. Завдяки належному об'єднанню цих даних і даних, зібраних після розгортання різних компонентів тієї чи іншої ОПМ, і їх використанню в сполученні 3 географічними інформаційними системами (ГІС) можна було б створити могутні інструменти для виявлення потреб і проблем у районі здійснення місії, а також для оцінки віддачі, одержуваної в результаті реалізації планів дій. Отже, в складі кожної місії мають бути фахівці в області ГІС.

Ефективним навчальним посібником для персоналу місій і для сторін на місцях може бути моделювання за допомогою комп'ютера. Може бути змодельований будь-який компонент тієї чи іншої операції. Це моделювання може полегшити групове рішення проблем і продемонструвати сторонам на місцях ті наслідки їх рішень у питаннях політики, які вони не в змозі передбачити. За наявності відповідного доступу до Інтернету комп'ютерне моделювання може стати частиною посібників для дистанційного навчання, складених з урахуванням тієї чи іншої нової операції і використовуваних для попередньої підготовки новобранців у складі місії.

Деякі компоненти місій, зокрема, як цивільна поліція і пов'язані з нею підрозділи карного правосуддя і співробітники, що займаються розслідуваннями порушень прав людини, мають потребу в захисті мережі, а також програмному забезпеченні для збереження, передачі й аналізу даних. Двома найважливішими технологіями в цьому аспекті є програма ГІС і програма складання карти злочинності, що використовуються для перетворення неопрацьованих даних у географічні добірки, що показують тенденції в злочинності і містять 
ін. найважливіші дані, полегшують задачі встановлення внутрішніх зв'язків між подіями чи вказують на характерні риси проблемних районів, що сприяє розширенню можливості цивільної поліції боротися із злочинністю чи консультувати своїх колег з місцевих правоохоронних органів.

Висновки. Отже, існує нагальна потреба підвищення ефективності інформаційної структури і практики Організації, для того щоб вона могла більш ефективно виконувати свої функції з підтримки миру і безпеки.

Очевидно, що велика увага повинна бути приділена необхідності більш ефективної координації ходу виконання програм роззброювання, демобілізації і реінтеграції, а для цього життєво необхідним є якнайшвидший збір інформації та iii ефективний аналіз, як на рівні самого інформаційного відділу Місії, так і в Центральних установах. Але, незважаючи на ефективну координацію та вдосконалений план дій, одним з вирішуючих факторів успішного виконання мандату є адекватне і своєчасне фінансування цих програм.

Діiі, пов'язані з запобіганням кризи, мають на увазі добре інформовану політичну підтримку, що забезпечить постійне інформування ООН про розвиток ситуації в рамках регіону та про ключові фактори. Миротворцям необхідно більше інформації про варіанти своєї діяльності. Місії не повинні створювати власну контактну мережу. Вони повинні точно знати, до кого звернутися за необхідними відповідями і підтримкою. Крім того, вони повинні мати можливість одержати відповідь на ці питання в одному місці, у структурі, що включає весь необхідний для місії персонал.

В результаті аналізу дій у рамках ОПМ зрозуміло, що рівень секретаріатської підтримки цих місій недостатній, тому для покращення діяльності в цій області потрібні додаткові зусилля та ресурси. Протягом останніх років постійні представники при $\mathrm{OOH}$, а також незалежні спостерігачі говорили, що недоліки, які маються в діяльності ООН із забезпечення миру $\mathrm{i}$ безпеки, не можуть бути виправлені без значних фінансових ресурсів. Крім підвищення фінансування, що є очевидним, для покращення діяльності ООН у сфері миру та безпеки потрібне створення ефективної системи для накопичення знань.

Оскільки кожен з елементів, задіяних в ОПМ, має свою культуру, методи роботи і цілі, усі вони мають потребу в механізмі, що полегшував би ефективний обмін інформацією та ідеями. Для цього потрібно, щоб один із підрозділів системи $\mathrm{OOH}$ на рівні Центральних установ займався питаннями інтеграції інформаційних технологій, розробкою і здійсненням стратегії в області інформаційних стандартів для користувачів. Одним 3 кроків для налагодження інтегрування і спільного використання інформації повинне бути створення $\mathrm{i}$ ведення каталогу ресурсів інформаційних систем і комунікаційних технологій, пов'язаних з ОПМ. 
Нинішні конфлікти мають безліч аспектів, які вимагають всеосяжного підходу і більш погоджених і скоординованих дій, тому механізми обміну інформацією і координації між департаментами, а також з іншими підрозділами системи, повинні бути поліпшені. ВКМБ повинен сприяти співробітництву між департаментами, зокрема у відношенні збору й аналізу інформації. CICA має являти собою центр для накопичення та аналізу знань для працівників всіх структур системи ООН, що має важливе значення для розуміння вихідних причин конкретних конфліктів. Для цього потрібно застосування комплексного підходу.

Операціям з підтримки миру могло б сприяти широке використання ГІС, що забезпечує швидке інтегрування оперативних відомостей з електронними картами району дій місії. Крім того, таким компонентам місії, як цивільна поліція i компонент по правах людини, що володіють унікальними інформаційними потребами, потрібна додаткова увага. Необхідно вміти прогнозувати i більш послідовно враховувати іх інформаційні потреби при плануванні і проведенні місії.

Головними умовами успіху комплексних операцій $\epsilon$ політична підтримка, швидке розгортання сил і ефективне стратегічне планування. Не можна не наголосити на необхідності того, щоб ООН продовжувала налагоджувати взаємодію 3 цивільним суспільством і зміцнювала зв'язки 3 неурядовими організаціями, академічними інститутами і ЗМI, що $є$ важливими партнерами в справі сприяння забезпеченню миру і безпеки для усіх.

Автор впевнений, що надалі успіх операцій буде залежати від здатності $\mathrm{OOH}$ забезпечувати єдність цілей різних підрозділів, що дозволить ій діяти узгоджено і використовувати свої ресурси на стратегічно важливих напрямах. Щоб домогтися успіху, ООН повинна зосередити свою увагу на аспектах діяльності, що вдаються їй краще інших.

\section{Список використаних джерел:}

1. Департамент общественной информации [Электронный ресурс] // Организация Объединенных Наций : [сайт]. - Режим доступа: http://www.un.org/ru/sections/department-public-information/department-publicinformation/department-public-information/index.html. - Назва 3 екрану. - Дата звернення: 06.02.2018.

2. Департамент операций по поддержанию мира [Электронный ресурс] // Организация Объединенных Наций : [сайт]. - Режим доступа: http://www.un.org/ru/peacekeeping. - Назва з екрану. - Дата звернення 06.02.2018.

3. Доклад Генерального секретаря Совету Безопасности ООН. Повестка дня для мира. Превентивная дипломатия, миротворчество и поддержание мира. А/47/277 - S/24111. - ДОИ. - Нью-Йорк, 1992. 
4. Официальные документы Генеральной Ассамблеи. Доклад Генерального секретаря ООН «Мы, народы: роль ООН в XXI столетии». А/54/20. - ДОИ. - Нью-Йорк, 1999.

5. Официальные документы Генеральной Ассамблеи. Утвержденные ресурсы на операции по поддержанию мира на период с 1 июля 2012 года по 30 июня 2013 года. А/С.5/66/18. - ДОИ. - Нью-Йорк, 2012.

\section{References:}

1. United Nations. Department of Public Information. [online] Available at : http://www.un.org/ru/sections/department-public-information/department-publicinformation/department-public-information/index.html. [Accessed 6 February 2018]. Title from the screen.

2. United Nations. Department of Peacekeeping Operations. [online] Available at : http://www.un.org/ru/peacekeeping. [Accessed 6 February 2018]. Title from the screen.

3. DPI. (1999). Report of the Secretary General to the UN Security Council. An agenda for the world. Preventive diplomacy, peacemaking and peacekeeping. A / 47/277-S / 24111. New York.

4. DPI. (1999). Official documents of the General Assembly. Report of the Secretary-General of the United Nations "We are the peoples: the role of the United Nations in the twenty-first century". A / 54/20. New York.

5. DPI. (2012). Official documents of the General Assembly. Approved resources for peacekeeping operations for the period from 1 July 2012 to 30 June 2013. A / C.5 / 66/18. New York.

(C) Степко О. М., 2018 